九州大学学術情報リポジトリ

Kyushu University Institutional Repository

\title{
Studies on the marine yeasts. VII : On the utilization of plankton and seaweeds by yeasts
}

Suehiro, Sumio

Laboratory of Chemistry of Fishery Product, Faculty of Agriculture, Kyusyu University

Tomi yasu, Yukio

Laboratory of Chemistry of Fishery Product, Faculty of Agriculture, Kyusyu University

https://doi.org/10.5109/22721

出版情報: 九州大学大学院農学研究院紀要. 13 (1)，pp.227-235，1964-03. Kyushu University バージョン：

権利関係 : 
Journal of the Faculty of Agriculture, Kyushu University, Vol. 13, No. 1

March 30, 1964

Studies on the marine yeasts. VII

On the utilization of plankton and seaweeds by yeasts

Sumio Suehiro* and Yukio TomiYasu $†$

The authors reported $^{1,2)}$ that a remarkable development of yeast was always observed in the flask in which plankton or seaweeds had been kept at $20^{\circ} \mathrm{C}$ for several days in the presence of chlortetracycline (CTC) and citric acid. The present investigation was carried out not only to clarify the mechanism of the utilization of plankton and seaweeds by the yeasts, but also to find out the difference between the growth of the yeasts and that of the bacteria, both developing on the decaying plankton or seaweeds.

I) The mechanism of the utilization of plankton by the yeasts

a) The utilization of the dissolved substances liberated from plankton by shaking

It has been known that some marine plants produce "extracellular products,"-+>" such as sugars, organic acids, vitamins, and peptides etc. Yanagizawa") reported that a considerable amount of phosphates and silicates was liberated from plankton, while it was being shaken immediately after the collection. It has been also pointed out that some of these products are utilized by certain algae ${ }^{10)}$ and some marine bacteria. ${ }^{11,12)}$ To ascertain whether the yeasts also utilize them, the following experiment was carried out.

About $1,500 \mathrm{ml}$ of towed sea water, a phytoplankton sample, was

* Fishery Research Laboratory, Kyushu University, Tsuyazaki, near Fukuoka.

$\dagger$ Department of Fisheries, Kyushu University, Fukuoka.

\$ The towed sea water was obtained with a phytoplankton-net, the opening of which was covered with bolting silk (G.G. 54) to prevent the zooplankton from entering it. But it was impossible completely to exclude the zooplankton larvae of the same size as phytoplankton. 
poured into a $3,000 \mathrm{ml}$ flask. Then it was shaken with 125 strokes per min. through a distance of $5 \mathrm{~cm}$ at room temperature $\left(18^{\circ} \mathrm{C}\right)$. After shaking for $0.5,1,2$, and $4 \mathrm{hr}$., $250 \mathrm{ml}$ being taken each time, each sample was filtered with a paper respectively. CTC $(50 \mathrm{ppm})$ and citric acid ( $200 \mathrm{ppm}$ ) were then added to the filtrates, and the filtrates were maintained at $20^{\circ} \mathrm{C}$. As a control test, the two compounds were added to the unfiltered towed sea water collected at the same time, and it was maintained at $20^{\circ} \mathrm{C}$. A considerable number of developing yeasts were observed in all the cases within several days. (Since yeasts attach themselves to plankton in the sea, there is no need of inoculation.) The method of counting the number of the yeasts developing was similar to that in the previous reports?) Each maximal number of the yeasts developing is shown in Table $\mathbf{1}$.

Table 1. Maximal numbers of yeast in the filtrate of phytoplankton shaken.

\begin{tabular}{l|cccccc}
\hline Time of shaking in hr. & 0 & 0.5 & 1.0 & 2.0 & 4.0 & Control \\
$\begin{array}{c}\text { Number fuff the veasts } \\
\text { in each fiftrate per ml }\end{array}$ & $5 \times 10^{5}$ & $6 \times 10^{5}$ & $9 \times 10^{5}$ & $2.5 \times 10^{6}$ & $3 \times 10^{6}$ & $\mathbf{1 . 5} \times \mathbf{1 0 ^ { 7 } .}$
\end{tabular}

The yeasts were ascertained to utilize the dissolved substances liberated from plankton by shaking, and almost all of the excretable substances, available to the yeasts, seemed to be liberated within four hr. shaking. The maximal number of the yeasts developing in the control test was about $1.5 \times 10^{7} / \mathrm{ml}$, and that in the filtrate (four hr. shaking) was about $3 \times 10^{6} / \mathrm{ml}$. Hence the amount of the liberated substances, available to the yeasts, in the filtrate seemed to attain about $20 \%$ of the whole available substances of the plankton. A considerable development of yeast in the filtrate $(0 \mathrm{hr}$ shaking) shows that a considerable amount of dissolved substances was liberated from the plankton before the experiment. They seemed to be liberated by the stimulation given to the plankton during the collection and by the vibration of the boat (for about $20 \mathrm{~min}$.) caused by the engine.

b) The utilization of the dissolved substances liberated from plankton by autolysis

As the marine yeasts seem to be saprophytic and their growth may be affected by the autolysis of plankton when decaying, the effect of the autolysis was investigated as follows: about $1,500 \mathrm{ml}$ of towed sea water, a phytoplankton sample, was maintained at $45^{\circ} \mathrm{C}$, and $250 \mathrm{ml}$ was taken from it after $0.5,1,2,4$, and $8 \mathrm{hr}$. respectively. Each sample was filtered with a paper, and after the addition of the two compounds, 
each of them was inoculated with one drop of yeast suspension* and incubated at $20^{\circ} \mathrm{C}$ for several days. As a control test, the two compounds were added to the unfiltered towed sea water collected at the same time, and it was maintained at $20^{\circ} \mathrm{C}$ for several days. Table 2 shows maximal numbers of the yeasts.

Table 2. Maximal numbers of yeast in the filtrate of plankton maintained at $45^{\circ} \mathrm{C}$.

\begin{tabular}{|c|c|c|c|c|c|c|}
\hline $\begin{array}{l}\text { Time of maintaining } \\
\text { in } \mathrm{hr} \text {. }\end{array}$ & 0.5 & 1.0 & 2.0 & 4.0 & 8.0 & Control \\
\hline Number Phytoplankton & $7 \times 10^{6}$ & $1.2 \times 10^{7}$ & $1.7 \times 10^{7}$ & $1.9 \times 10^{7}$ & $1.9 \times 10^{7}$ & $1.9 \times 10^{7}$ \\
\hline per ml Zooplankton & $6 \times 10^{6}$ & $1 \times 10^{7}$ & $1.2 \times 10^{7}$ & $1.6 \times 10^{7}$ & $1.6 \times 10^{7}$ & $1.6 \times 10^{7}$ \\
\hline
\end{tabular}

Thus, all of the available substances of the plankton seemed to be dissolved at $45^{\circ} \mathrm{C}$ within four hr., because the number of the yeasts developing in the filtrate (four hr.) was almost equal to that of the yeasts developing in the control. Similar results were obtained in the experiment with a zooplankton sample.

c) The ability of the yeasts in directly decomposing the plankton

As mentioned above, the yeasts were ascertained to utilize the dissolved substances liberated from the plankton by autolysis. It was further investigated whether the yeasts could directly decompose plankton without the aid of autolysis.

About $500 \mathrm{ml}$ of towed sea water was divided into two parts, and the two compounds were added to one of them as a control test. (A) The other was boiled for five min. to eliminate the influence of autolysis, and filtered with a paper. (B) The residue was washed well with distilled water to remove the soluble substance completely and resuspended in the sea water of the same volume as the filtrate. (C) Then the two compounds were added to $\mathrm{B}$ and $\mathrm{C}$, and each of them was inoculated with one drop of yeast suspension. These three samples were maintained at $20^{\circ} \mathrm{C}$ for several days. The number of the yeasts developing in them is shown in Figs. 1 (phytoplankton) and 2 (zooplankton).

As a result, the yeasts were found to be able to decompose some parts of the plankton. The number of the yeasts developing in the control, however, was larger than the total of those in B and C, and the growth rate of the yeasts in $\mathrm{C}$ was far smaller than that in $\mathrm{A}$.

* The yeast suspension was obtained by keeping the towed sea water at $20^{\circ} \mathrm{C}$ for several days in the presence of the two compounds. In the suspension, $1.5 \times$ $10^{7} / \mathrm{ml}$ of yeast was observed. 
Therefore, it is considered that, when the plankton is decaying, the yeasts utilize the dissolved substances liberated from the plankton

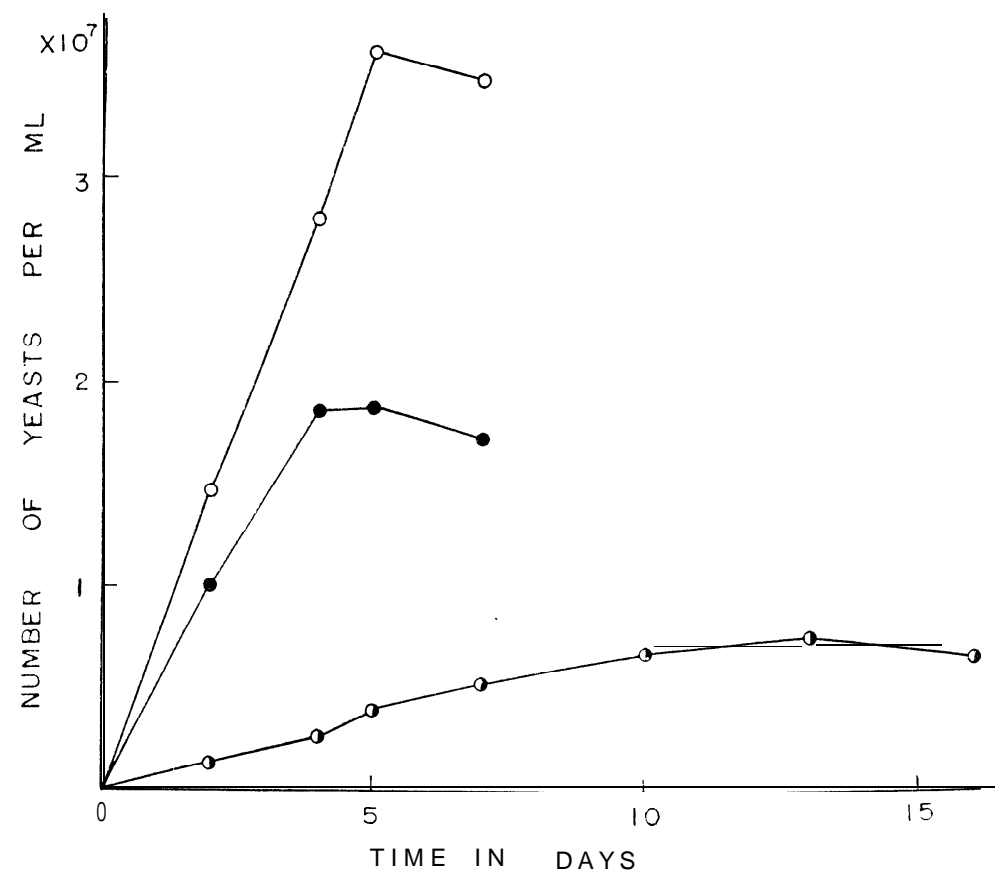

Fig. 1. Number of yeasts developing in filtrate and residue of phytoplankton, - 0 - Control, - - Filtrate, - Residue

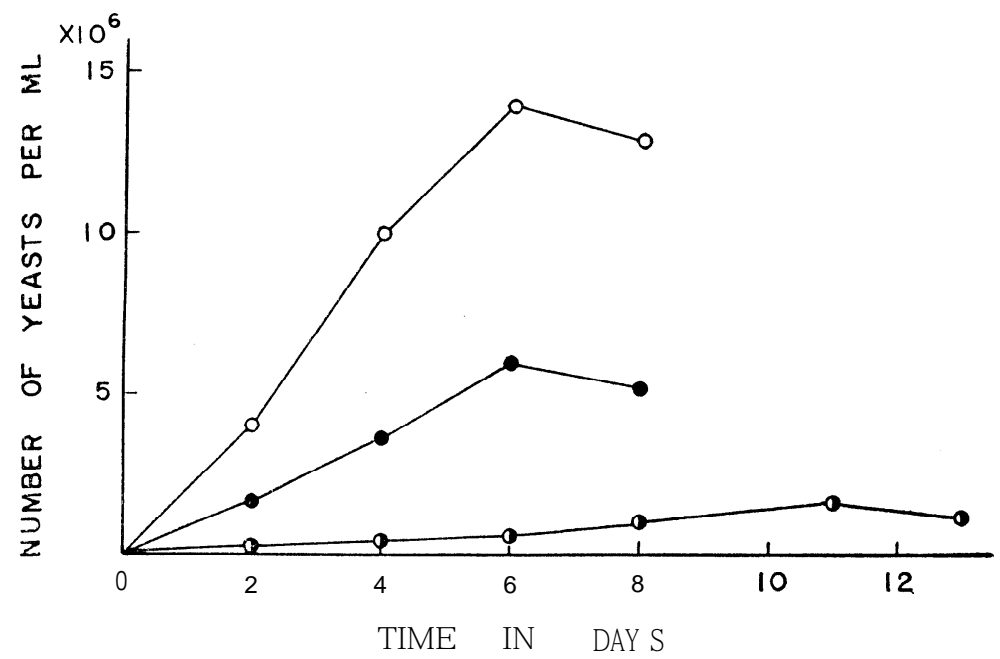

Fig. 2. Number of yeasts developing in filtrate and residue of zooplankton. $-\mathrm{O}$ - Control, 
more than the insoluble* substances of the plankton.

Further, about $50 \%$ of the available substances of the plankton seemed to be dissolved by boiling.

II) The difference between the growth of the yeasts and that of the bacteria, both developing on decaying plankton

When a plankton sample is kept in a flask, the development of bacteria alone is generally observed, but in the presence of the two compounds, on the other hand, only a number of developing yeasts are invariably found. To find out the difference between the growth of the yeasts and that of the bacteria, both developing on decaying plankton, the following experiment was carried out.

About $500 \mathrm{ml}$ of towed sea water, a phytoplankton sample, was divided into two parts. The two compounds were added to one of them, and both were maintained at $20^{\circ} \mathrm{C}$ for several days. The number of developing yeasts was estimated with the treated one, and that of bacteria with the non-treated. The results are shown in Fig. 3.

As shown in Fig. 3, the number of bacteria rapidly decreased after four days' incubation, and the sea water in the non-treated flask became almost clear in seven days at the latest. These bacteria seemed to become the food of the protozoa in the water. To eliminate the influence of protozoa, therefore, the following experiment was carried out.

About $900 \mathrm{ml}$ of towed sea water, a phytoplankton sample, was divided and put in three flasks (A, B, and C). A and B were held at $45^{\circ} \mathrm{C}$ for four hr. and boiled for five min. to kill the protozoa. After adding the two compounds to A, one drop of yeast suspension was added

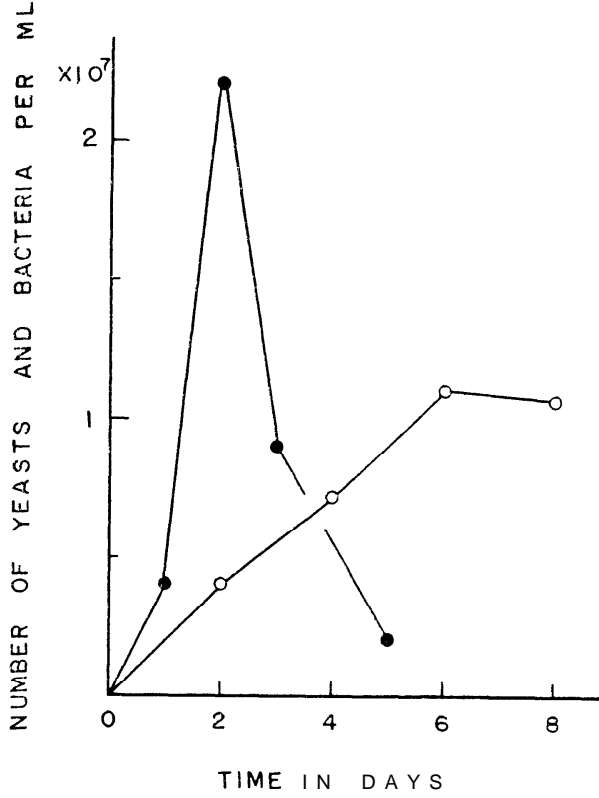

Fig. 3. Number of yeasts and bacteria, both developing on phytoplankton.

- - Number of yeasts,

- Number of bacteria

* In this case " insoluble" means unable to be dissolved by boiling, though, in fact, these substances are available to the yeasts if they are dissolved by some other means. 
to it. B was inoculated with one drop of the mixture of various bacterial suspensions $\left(2 \times 10^{7} / \mathrm{ml}\right)$, the bacteria being isolated from decaying plankton. No treatment was given to $\mathrm{C}$. These three samples were then maintained at $20^{\circ} \mathrm{C}$ for several days. The number of developing yeasts was determined with $\mathrm{A}$, and that of bacteria with $\mathrm{B}$, and that of bacteria developing together with protozoa with C. The results are shown in Fig. 4.

The number of bacteria developing in $\mathrm{B}$ was far greater than that

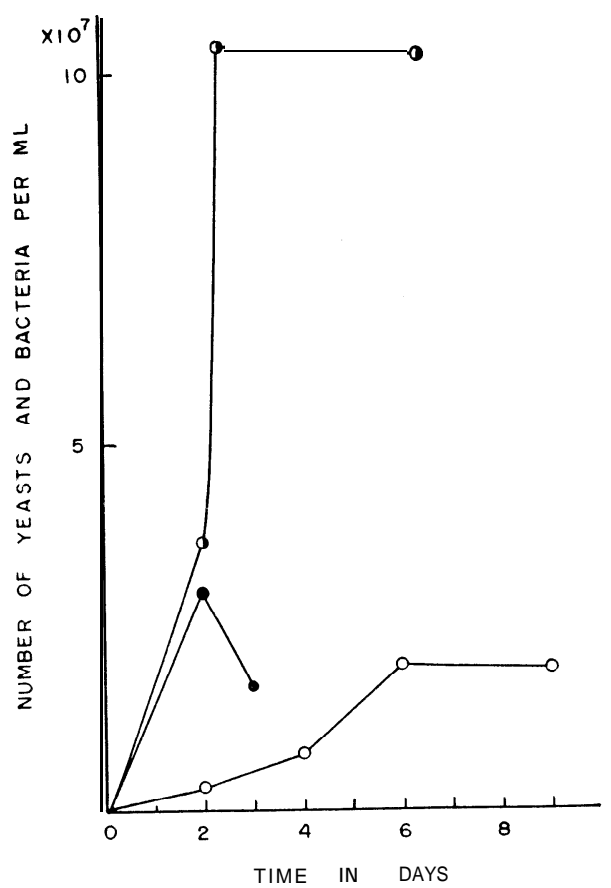

Fig. 4. Number of yeasts and bacteria, both developing on phytoplankton.

\footnotetext{
- - Number of yeasts,

- Number of bacteria,

- Number of bacteria developing together with protozoa.
} of those developing in $\mathrm{C}$, and that of the former did not decrease for a long period. From these results, it can be assured that the bacteria in $\mathrm{C}$ became the food of the protozoa.

If we suppose that a cell of yeast is a ball of $4 \mu$ in diameter and that of bacteria of $1 \mu$, the volume of a cell of yeast will be 64 times as large as that of bacteria. Consequently, the total volume of the yeasts in A must be more than 15 times as large as that of bacteria. This was also substantiated by the fact that the turbidity of A was far greater than that of B.

In the case of zooplankton (Doliolum sp.), the ratio of the total volume of yeasts to that of bacteria was found to be $5: 1$.

III) The decomposition of seaweed by the yeasts

During the decomposition of plankton, the growth of the yeasts was found to be greatly accelerated by autolysis. A similar result may be expected in the case of seaweeds.

After putting $20 \mathrm{~g}$ of a seaweed (Codium fragile) and $200 \mathrm{ml}$ of sea water in three flasks respectively, the two compounds were added 
to one of them as a control test. (A) Another flask was maintained at $45^{\circ} \mathrm{C}$ for $24 \mathrm{hr}$. and then filtered with a paper. (B) The remaining one was boiled for ten min. to eliminate the influence of autolysis and filtered with a paper. (C) The residue was washed well with distilled water to remove the soluble substances completely, and resuspended in the sea water of the same volume as the filtrate. (D) Then B, C and $\mathrm{D}$ were each inoculated with a drop of yeast suspension, and all the four samples were maintained at $20^{\circ} \mathrm{C}$ for several days. The number of the yeasts developing in them is shown in Fig. 5.

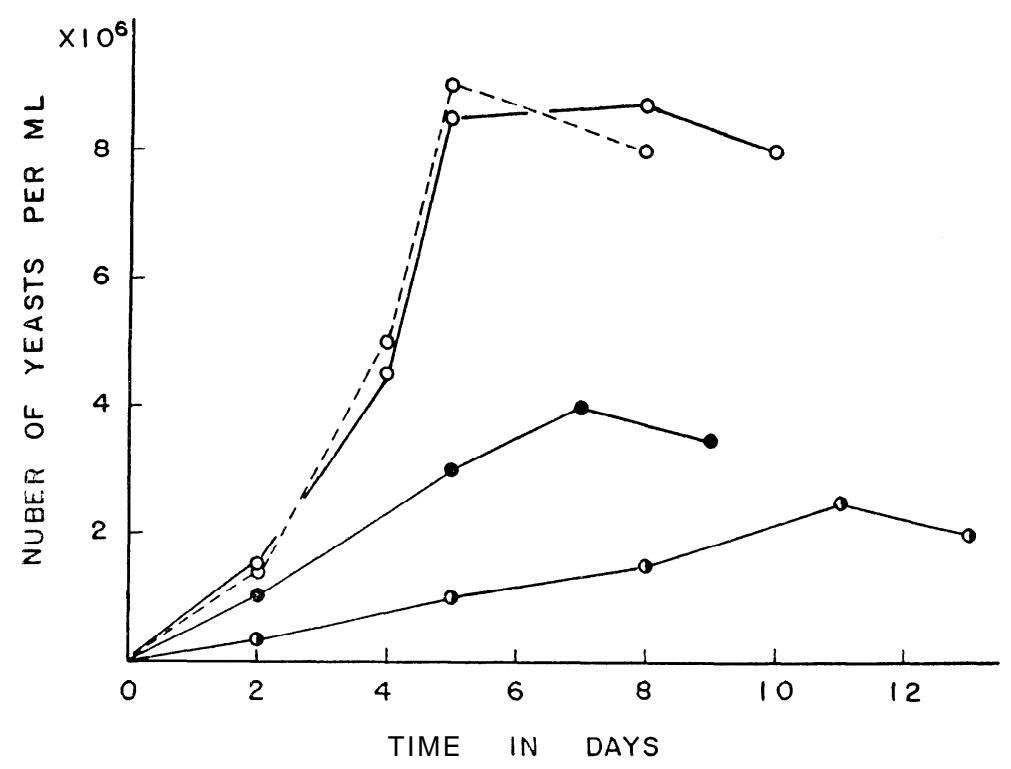

Fig. 5. Number of yeasts developing on Codium fragile variously treated.

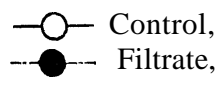

- Autolyzated,

- - Residue.

As shown in Fig. 5, all of the available substances of the seaweed were found to be dissolved by autolysis. The growth of the yeasts was also found to be greatly accelerated by autolysis when the seaweed was decaying, though the yeasts, of course, could decompose it to some extent.

Moreover, it was found that the total volume of the yeasts developing on the decaying Codium fragile was only a little more than two times as large as that of bacteria. The volume of the yeasts developing on the decaying seaweed was far smaller than that of those developing on decaying plankton. As mentioned in the previous reports, ${ }^{13)}$ however, the number of the yeast developing on decaying seaweeds 
varied with the species and the season. So the ratio of the total volume of the yeasts to that of the bacteria, both developing on decaying seaweeds, must vary with them. During the decomposition of plankton or seaweeds in the sea, the function of the marine bacteria seems to consist usually in the mineralization of them, but from the results mentioned above, it was found that the function of the marine yeasts differed considerably from that of the bacteria and that the role of the yeasts in the life cycle in the sea is by no means negligible.

In the sea, however, the growth of the yeasts is observed not only on decaying plankton and seaweeds, but also on living ones. In the case of living plants, the yeasts may utilize the "extracellular products." By way of example, a remarkable development of yeast was observed in the flask in which the culture of Thalassiosirasubtilis (marine diatom), having been cultured for one year through subculturing it once a week, had been kept at $20^{\circ} \mathrm{C}$ in the presence of the two compounds? (The medium used for culturing the diatom was "ASP II " designed by Provasoli ${ }^{15)}$ prepared with distilled water.) This fact, therefore, indicates that the yeasts had grown together with the diatom at least for one year. Moreover, during the first two days, the veasts developing were the members of Rhodotorula or Cryptococcus only, and after seven days, when the number of the yeasts was at its maximum, almost all of them were found to belong to Candida. This phase of the development of various yeasts is quite similar to that of the collected diatom, T. subtilis, kept under the same condition. It is considered, therefore, that the yeast biota, growing together with the diatom in its culture, is similar to that attaching itself to the diatom in the sea. So in the sea symbiotic relationship seems to exist between the yeasts and the diatom.

Furthermore, such cultures of yeasts as show high salt tolerance $(20 \% \mathrm{NaCl})$ were isolated from seaweeds in intertidal zone. ${ }^{16)}$ On the surface of seaweeds the cultures seem to get such a high degree of tolerance because the salt concentration becomes higher in low tide due to evaporation. Moreover, in attaining such high tolerance, they must always attach themselves to seaweeds. It is considered that the marine yeasts are widespread in the sea, and some of them grow symbiotically with phytoplankton or seaweeds. Further work in progress involves the investigation to elucidate the symbiotic relationship between yeasts and phytoplankton or seaweeds.

\section{S UMMAR Y}

1) The yeasts could utilize the dissolved substances liberated from living phytoplankton by shaking (125 strokes/min., distance of $5 \mathrm{~cm}$ ). 
Almost all of the excretable substances, available to the yeasts, were liberated within four hr shaking. The amount of them was about $20 \%$ of the whole available substances of the plankton.

2) When plankton or seaweeds were decaying, it was found that the growth of the yeasts was extremely accelerated by their autolysis and that the yeasts utilize the dissolved substances liberated from the plankton or seaweeds more than the insoluble substances of them.

3) The total volume of the yeasts developing on decaying plankton was more than 5-15 times as large as that of the bacteria, while in the case of a certain seaweed, that of the yeasts was only a little more than two times as large as that of the bacteria.

\section{R E F ER E N C ES}

1) Suehiro, S. and Y. Tomiyasu, 1962. J. Fac. Agr. Kyushu Univ., 12: 163.

2) $\quad$--- 1962. Ibid. $12: 155$.

3) Allen, M. B., 1956. Arch. f. Mikrobiol., 24: 163.

4) Fogg, G. E., 1942. Lemn. J. Exp. Biol., 19: 78.

5) ---, 1950. Cohn. J. Exp. Bot., 1: 117.

6) --, 1952. Proc. Roy. Soc. London, 139 (B): 372.

7) , 1962. Physiology and Biochemistry of Algae. (ed. by R. A. Lewin) Academic Press, New York, London: 475.

8) Guillard, R. R. L., 1958. Limnol. Oceanog., 3: 449.

9) Yanagizawa, T. 1936. Kaiyo Kishodai Iho, No. 91.

10) Saunders, G. W. 1957. Bot. Rev., 23: 389.

11) Collier, A., 1958. Limnol. Oceanogr., 3: 33.

12) ZoBell, C. E., 1946. Marine Microbiology. Chronica Botanica, Waltham.

13) Suehiro, S. 1960. Sci. Bull. Fac. Agr. Kyushu Univ., 17: 443.

14) - , and Y. Tomiyasu, J. Fac. Agr. Kyushu Univ. (unpublished.)

15) Provasoli, L., J. J. A. McLaughlin, and M. R. Droop, 1957. Arch. f. Mikrobiol., 25: 392.

16) Suehiro, S. and Y. Tomiyasu, 1964. J. Fac. Agr. Kyushu Univ., 13: 213. 